DOI: https://10.15407/kvt197.03.065

UDC 519.8.812.007

N.I. ARALOVA, PhD (Engineering), Senior Researcher, Senior Researcher of the Department of Controlled Processes Optimization email: aralova@ukr.net

A.A. ARALOVA, PhD (Phys and Math.),

Researcher of the Department of Methods for Discrete Optimization, Mathematical Modelling and Analyses of Complex Systems

email: aaaralova@gmail.com

Glushkov Institute of Cybernetics of National Academy of Sciences of Ukraine, 40, Acad.Glushkov av., 03187, Kyiv, Ukraine

\title{
MATHEMATICAL MODELS OF CONFLICT CONTROLLED PROCESSES UNDER FUNCTIONAL SELF-ORGANIZATION OF THE RESPIRATORY SYSTEM
}

Introduction. Modern human life imposes more stringent requirements for ability to adapt to increasingly complex conditions, such as unfavorable environmental conditions, potential danger, increased responsibility, extreme physical exertion and their combined effect. This leads to a decrease in exercise tolerance, unfavorable changes in hemodynamic parameters, and disorders in the functional activity of other body organs and tissues. The decisive role in the adaptation of the organism to physical and psycho-emotional stress belongs to the oxygen transport system. However, at present, the possibilities of instrumental methods are rather limited, moreover, they can only characterize the state of the body at the current moment, and not predict its reserve capabilities in case of disturbances in the internal and external environment, in the process of recovery and rehabilitation.

Partially, this gap can be filled by mathematical models of the functional respiratory system, which allow to imitate disturbances of the internal and external environment of an organism in the dynamics of the respiratory cycle and, thus, predict possible controlling actions of the organs of self-regulation of the organism when adapting to these disturbances.

The purpose of the paper is to build a mathematical model of a functional respiration system that simulates resolving a conflict situation between executive and managing bodies of self-regulation in the conflict for oxygen, which allows predicting the parameters of selforganization of the respiratory system under internal and external disturbances.

Results. A mathematical model of mass transfer and mass transfer of respiratory gases in the human body is presented in the form of a system of non-linear differential equations, which is a controlled dynamic system, the state of which is determined at each time point by oxygen and carbon dioxide stresses in each structural link of the respiratory system (alveoli, blood and tissues). The control (self-regulation) of the condition under permanent or at a given time interval of the current disturbance (high functional activity of certain groups of tissues) is carried 
out by the self-regulation organs - respiratory muscles that form the necessary level of ventilation to compensate for the resulting hypoxic states, cardiac muscle providing the minute blood volume, and smooth muscles, vessels, vasodilation and vasocostriction which contributes to the distribution of systemic blood flow through the organs and tissues. There are also passive mechanisms of self-regulation: the concentration of hemoglobin in the blood, myoglobin in skeletal and cardiac muscles, their ability to oxygenate, the concentration of buffer bases in the blood etc. It is assumed that the decision on the choice of the values of compensating influences is made by the decision center based on the information activity and degree of oxygen deficiency, excessive accumulation of carbon dioxide in all tissue regions of the body, is transmitted to the executive bodies of self-regulation, increases their functional activity, which ensures the implementation of the main function of respiration.

Conclusion. The per-set mathematical model of the FRS allows the researcher to analyze the oxygen and carbon dioxide regimes of body in dynamics at various levels of functional load and under various environmental conditions; to form such regimes of the external respiration system, which contribute to an increase in the oxygen supply in the body and thereby increase the resource of the cardiac muscle during the regulation of hypoxic states that occur when the combined effects of hypobaric hypoxia and hypermetabolic hypoxia; predict the state of the body during various physical efforts and evaluate the effectiveness of the preparation process; plan and distribute heavy loads, taking into account the functionality of the individual and depending on the prevailing situations. The work presents the results of numerical experiments with a model for simulating internal (physical activity) and external (hypoxic hypoxia) disturbances on the human body.

Keywords: conflict-controlled processes, a functional system of respiration, functional selforganization of the respiratory system, adaptation to stress.

\section{INTRODUCTION}

It is known that the human body adapts to the changing conditions of vital activity, no matter how extreme they are. All human activity is carried out under certain environmental conditions and in certain neuromuscular stress, characterized by human exposure to a number of factors that alter the physiological and functional parameters.

Body functions can be performed only when the environment meets its needs, can normally be carried out only under the condition that the environment meets their needs. If environmental conditions become unfavorable and complicate human activity, it leads to reduced exercise tolerance, adverse changes in hemodynamic, functional disorders of the activities of other organs and tissues. Combined with such factors as increased responsibility, the potential danger of surprise, novelty, increased intellectual complexity, these conditions due to the large load on the psyche can cause excessive stress adaptation systems of the organism, various reactions and adverse psychological state.

It is known that a decisive role in the body's adaptation to physical and emotional load belongs to oxygen transport system [1]. Comprehensive study of oxygen supply systems of human body in the process of adaptation to the new conditions of life and new activities reveals the leading units in the cascade of compensatory reactions and evaluate the functional reserves of the organism.

Currently, however, the possibility of only instrumental methods are rather limited, besides, they can only characterize the condition of the body only in the moment, not possible to predict its reserve under perturbations of internal and external environment, in the process of recovery and rehabilitation. 
Partially fill this gap may mathematical model of the respiratory system $[2,3,4]$ allowing to simulate the dynamics of the respiratory cycle perturbation internal and external environment, and thus possible to predict the reaction of the organism to these disturbances.

All of the functional systems of the body somehow react in response to the disturbing internal or external influences, trying to stabilize. Naturally, they interact with one another, despite the contradictions between the goals and interests. Development of the theory of dynamic games, optimal control theory and numerical optimization methods have created the preconditions for the creation of mathematical, algorithmic and software for simulation of various disturbances. Mathematical models of functional systems and simulation complement system experimental and clinical data obtained by the tool.

\section{MATHEMATICAL MODEL}

Presented model describes the transport and mass exchange of respiratory gases in various respiratory system links - airway, alveolar spaces of the lungs, the blood of lung and tissue capillaries, arterial and mixed venous blood, tissue vessels and organs (brain, heart, respiratory and skeletal muscle, and other tissues and organs) and compensating feedback mechanisms of self (the quantity of ventilation, cardiac output and systemic organ (tissue), blood flow, stabilizing the functional state of the organism and given the level of its functional activity.

As the phase variables by which the estimated state functional breathing and circulation system selected oxygen partial pressure of respiratory gases, carbon dioxide and nitrogen in the respiratory tract $\left(p_{R W} \mathrm{O}_{2}, p_{R W} \mathrm{CO}_{2}, p_{R W} N_{2}\right)$ and alveolar spaces $\left(p_{A} \mathrm{O}_{2}, p_{A} C \mathrm{O}_{2}, p_{A} N_{2}\right)$ and the voltage in the arterial $\left(p_{a} \mathrm{O}_{2}\right.$, $\left.p_{a} \mathrm{CO}_{2}, p_{a} N_{2}\right)$, mixed venous $\left(p_{\bar{v}} \mathrm{O}_{2}, p_{\bar{v}} \mathrm{CO}_{2}, p_{\bar{v}} N_{2}\right)$, blood pulmonary capillaries $\left(p_{l c} \mathrm{O}_{2}, \quad p_{l c} \mathrm{CO}_{2}, \quad p_{l c} N_{2}\right)$, tissue blood capillaries $\left(p_{c t_{i}} \mathrm{O}_{2}\right.$, $\left.p_{c t_{i}} C \mathrm{O}_{2}, p_{c t_{i}} N_{2}\right)$ and tissue fluids $\left(p_{t_{i}} \mathrm{O}_{2}, p_{t_{i}} \mathrm{CO}_{2}, p_{t_{i}} N_{2}\right)$.

Depending on mathematical modeling purposes, for evaluating the functional status of the system the apparatus of the differential equations with lumped or distributed parameters is used. In this case the mathematical model functional respiratory system is used to study the mechanisms of self-regulation and adaptation to internal and external disturbances, the dynamic partial pressures and respiratory gases stresses in the organism described by a system of ordinary differential equations. They are based on the principles of mass balance and flow continuity.

The parametric form can be written as follows:

$$
\begin{gathered}
\frac{d p_{i} O_{2}}{d \tau}=\varphi\left(p_{i} O_{2}, p_{i} C O_{2}, \eta_{i}, \dot{V}, Q, Q_{t_{i}}, G_{t_{i}} O_{2}, q_{t_{i}} O_{2}\right) \\
\frac{d p_{i} C O_{2}}{d \tau}=\varphi\left(p_{i} O_{2}, p_{i} C O_{2}, \eta_{i}, \dot{V}, Q, Q_{t_{i}}, G_{t_{i}} C O_{2}, q_{t_{i}} C O_{2}\right)
\end{gathered}
$$


where the functions $\varphi$ and $\phi$ described in detail in [3,4], $\dot{V}-$ ventilation, $\eta$ - the degree of oxygen saturation of hemoglobin, $Q$ - the space velocity of the system and $Q_{t_{i}}$ - local blood flow, $q_{t_{i}} O_{2}-$ rate of oxygen consumption $i$ - the tissue reservoir $q_{t_{i}} \mathrm{CO}_{2}$ - the rate of release of carbon dioxide in $i$ - st fabric reservoir. Velocity $G_{t_{i}} O_{2}$ oxygen from the blood stream into the tissue and $\mathrm{G}_{t_{i}} \mathrm{CO}_{2}$ carbon dioxide from the tissue into the blood is determined by the relation:

$$
G_{t_{i}}=D_{t_{i}} S_{t_{i}}\left(p_{c t_{i}}-p_{t_{i}}\right),
$$

where $D_{t_{i}}-$ gas permeability coefficients throe the air-blood barrier, $S_{t_{i}}$ - surface area of gas transfer.

The purpose of the control [5] is output perturbed system in a stationary mode in which the relations

$$
\left|G_{t_{i}} O_{2}-q_{t_{i}} O_{2}\right| \leq \varepsilon_{1},\left|G_{t_{i}} C O_{2}+q_{t_{i}} C O_{2}\right| \leq \varepsilon_{2},
$$

where $\varepsilon_{1} \cdot \varepsilon_{2}$ predefined sufficiently small positive number. Thus on the control parameters are imposed restrictions

$$
0 \leq \dot{V} \leq \dot{V}_{\max }, 0 \leq Q \leq Q_{\max }, 0 \leq Q_{t_{i}} \leq Q, \sum_{i=1}^{m} Q_{t_{i}}=Q,
$$

where $m$ - the number of vessels in the body tissue.

In addition, to resolve a conflict between the executive regulation (respiratory muscles, cardiac muscles and smooth muscles of blood vessels), which are at the same time oxygen consumers and other tissues and organs [5] introduced ratios

$$
q_{\text {resp. .m. }} O_{2}=f(V), q_{\text {card. } . .} O_{2}=\phi(Q), q_{\text {sm.m. }} O_{2}=\varphi(Q) .
$$

As a criterion for considering the functional regulation

$$
\begin{aligned}
& I=\min _{\substack{0 \leq V \leq V_{\max } \\
0 \leq Q_{t_{i}} Q_{\operatorname{Qmax}}}} \int_{\tau_{0}}^{T}\left[\rho_{1} \sum_{t_{i}} \lambda_{t_{i}}\left(G_{t_{i}} O_{2}-q_{t_{i}} O_{2}\right)^{2}+\rho_{2} \sum_{t_{i}} \lambda_{t_{i}}\left(G_{t_{i}} C O_{2}+q_{t_{i}} C O_{2}\right)^{2}\right] d \tau, \\
& i=\overline{1, m}
\end{aligned}
$$

where $\tau_{0}$ - the beginning of the impact of disturbance on the system, $T$ - the duration of the exposure, $\rho_{1}$ and $\rho_{2}$ - coefficients characterizing the particular sensitivity to hypoxia and hypercapnia, $\lambda_{t_{i}}-$ the coefficients reflecting the morphological features of a particular tissue reservoir $i$.

This control minimizes the total cost of the oxygen in the body and in every region of the tissue, as well as the accumulation of carbon dioxide.

Essentially, the model FSD is a controlled dynamic system whose state is determined at each time point voltages oxygen and carbon dioxide in each structural unit of the respiratory system (alveoli, blood and tissue). Control (autoregulation) state at constant or at a predetermined time interval of the current perturbation (high 
functional activity of the individual groups of tissues) is carried out by executive bodies selfregulation - respiratory muscles, forming the desired ventilation level to compensate for emerging hypoxic states, cardiac muscle, providing minute volume of blood and smooth muscles vascular tissue, vasodilatation and vastostriction which facilitates flow distribution system for body and tissues.

In addition to these active mechanisms of self-regulation in the model there are passive mechanisms: concentration of hemoglobin in the blood, myoglobin in skeletal and cardiac muscles, their ability to oxygenation, concentration of the buffer bases in the blood, etc. It is expected that the decision on the choice of the quantities of compensating actions taken center of decision-making on based on information about the level of functional activity and the degree of oxygen deficiency, excess accumulation of carbon dioxide in all parts of the tissue of the organism, is transferred to executive bodies of self-control, increasing their functional activity, which ensures the implementation of the basic functions of breathing.

\section{MATHEMATICAL MODEL OF THE SHORT-TERM ADAPTATION}

Short-term adaptation is almost instantaneous formation of functional systems of response to changing conditions or type of activity. Typically, the change of activity, the conditions under which flows human activity associated with a change in the level of metabolism, the metabolic processes in the tissues, the saturation level gases (oxygen, carbon dioxide, nitrogen and other trace gases) of blood and tissue fluid. Therefore a mathematical model of functional respiratory system sequentially describing the dynamics of oxygen stress, nitrogen, carbon dioxide in the body structures - the airway, the alveolar space, pulmonary capillary blood, arterial blood, blood tissue capillaries, tissue fluid and mixed venous blood to the respiratory cycle - becomes an effective tool for studying the state of the organism to various conditions of its activities. Especially it makes it possible to assess the development of hypoxia, acidosis in various structures of the body - blood, organs and tissues, which is not always possible to determine by experimentation in the laboratory or clinic.

As noted above, a functional respiratory system is seen as a controlled dynamic system. Each of nonlinear differential equations in the system, describes the changes in oxygen tension, carbon dioxide or nitrogen in these links the structure of the respiratory system in the respiratory cycle. All equations combined in describe mass transport and mass transfer of respiratory gases are controlled by the dynamic part of the respiratory system. The change in the respiratory gas in the respiratory system voltages structures significantly affect the magnitude of alveolar ventilation $V$ (and its defining - the value of the respiratory lung volume, duration of inhalation, pause and exhalation), the volume flow rate of the system $Q$ and the volumetric flow rate in the capillary beds of organs and tissues $Q_{e_{u}}, i=\overline{1, m}$. Therefore $V Q Q_{e_{u}}$ can be regarded as control parameters of the model. It is known that $V$ formed as a result of the work of the respiratory muscles, $Q$ determined by the work of the heart muscle, and $Q_{t i}, i=\overline{1, m}$ is the work of the smooth muscle tissue vessels. Therefore, it is reasonable to assume that the management of the operation of the respiratory 
system includes mechanisms for decision-making, forming structures of the brain, the executive bodies of the regulation - the respiratory muscles, heart and vascular smooth muscle tissue.

Perturbation acting on the respiratory system function can be subdivided into external - changing the composition of the breathing gas, the ambient pressure and the internal - changes in the intensity of metabolic processes in the tissues and organs, which are indicators of oxygen utilization rate $\left(q_{t_{i}} \mathrm{O}_{2}\right)$ and carbon dioxide gas $\left(q_{t_{i}} \mathrm{CO}_{2}\right)$. Regulation problem (self-, shortadaptation) of the respiratory system function is to derive the mass transfer of gases perturbed dynamical system in a new steady state which is stable to the conditions prevailing living organism.

Thus, the mathematical model of the short-term adaptation of functional respiratory system is a dynamic system management task. You must specify:

- the initial state of the system, characterized by phase variables: $p_{A} \mathrm{O}_{2}, p_{A} \mathrm{CO}_{2}, \quad p_{l c} \mathrm{O}_{2}, p_{l c} \mathrm{CO}_{2} \quad p_{a} \mathrm{O}_{2}, p_{a} \mathrm{CO}_{2}, \quad p_{c t_{i}} \mathrm{O}_{2}, p_{c t_{i}} \mathrm{CO}_{2}, p_{t_{i}} \mathrm{O}_{2}$, $p_{t_{i}} \mathrm{CO}_{2}, p_{\bar{v}} \mathrm{O}_{2}, p_{\bar{v}} \mathrm{CO}_{2}$, in the moment $\tau_{0}$, the start of exposure of disturbing factors on the system, the external and / or internal;

- the range of the control parameters:

$$
\left.\begin{array}{l}
\dot{V}_{\min } \leq \dot{V} \leq \dot{V}_{\max } \\
Q_{\min } \leq Q \leq Q_{\max } \\
Q_{C l_{\min }} \leq Q_{C l} \leq Q_{C l_{\max }}, j=\overline{1, m} \\
\sum_{j=1}^{m} Q_{C l}=Q
\end{array}\right\},
$$

- terminal region, a region of stable conditions for new living conditions, defined by the relation:

$$
\begin{gathered}
\left|G_{t_{i}} O_{2}-q_{t_{i}} O_{2}\right| \leq \varepsilon_{t_{i}} O_{2}, i=\overline{1, m} \\
\left|G_{t_{i}} C O_{2}+q_{t_{i}} C O_{2}\right| \leq \varepsilon_{t_{i}} C O_{2}, i=\overline{1, m},
\end{gathered}
$$

where $\varepsilon_{1 t i}, \varepsilon_{2 t i}$ - sufficiently small positive value.

Fulfillment of the conditions (8) ensures the stabilization of the oxygen pressure and carbon dioxide in the blood and tissues of the washer, which leads to the establishment of a new steady state.

Easy to see [6], so that the problem formulated short adaptation unit has a plurality of solutions. Any set $V, Q, Q_{t_{i}} i=\overline{1, m},(7)$, sooner or later leads to a state of a dynamic system, characterized by the condition (8), but the level of hypoxia and the degree of accumulation of carbon dioxide in the tissue will be more or less pronounced. We assume that the optimal set of control parameters $V, Q, Q_{t_{i}} i=\overline{1, m}, \sum_{i} Q_{t_{i}}=Q$ is a set of (7), which provides motion on the trajectories of the perturbed dynamical system minimizes the function: 


$$
I=\int_{\tau_{0}}^{T}\left(\rho_{1}\left(\sum_{t_{i}} \lambda_{t_{i}}\left(G_{t} O_{2}-q_{t_{i}} O_{2}\right)\right)^{2}+\left(\rho_{2} \sum_{t_{i}} \lambda_{t}\left(G_{t_{i}} C O_{2}+q_{t_{i}} C O_{2}\right)\right)^{2}\right) d \tau,
$$

where $\rho_{1}$ and $\rho_{2}$ sensitivity coefficients to hypoxia and hypercapnia, respectively, and $\lambda_{t_{i}}$ factors which characterize the functional - morphological features of each organ or tissue in the region. In this model it is assumed that

$$
\lambda_{t_{i}}=\phi\left(\frac{V_{c t_{i}}}{V_{t}}\right),
$$

which means that the recorded blood fullness unit volume of the tissue container. Thus modeled prevailing in the evolutionary process a vital importance of organ and tissue.

Upper limit $T$ in functional (9) is usually given a sufficiently small time (hundredths of seconds), since the short-term adaptation takes place almost instantaneously. If the condition (8) will occur in the $\tau<T$, the value

$I_{1}=\int_{\tau_{0}}^{T}\left(\rho_{1}\left(\sum_{t_{i}} \lambda_{t_{i}}\left(G_{t} O_{2}-q_{t_{i}} O_{2}\right)\right)^{2}+\left(\rho_{2} \sum_{t_{i}} \lambda_{t}\left(G_{t_{i}} C O_{2}+q_{t_{i}} C O_{2}\right)\right)^{2}\right) d \tau$

is almost equal to 0 and has little effect on the final value $I$.

It should be noted that the sensitivity coefficients $\rho_{1}$ and $\rho_{2}$ (9) are individual. For their establishment for a particular organism it is necessary to determine experimentally in a state of rest $q \mathrm{O}_{2}$ and $q \mathrm{CO}_{2}$ the whole organism, $V$ and $Q$, measure $p_{a} O_{2}$ and $p_{a} \mathrm{CO}_{2}$. Then the model with the parameter values established solves the problem of identification of functional (6) by changing the procedure $\rho_{1}$ and $\rho_{2}$ to obtain values $p^{\text {Mod }}{ }_{a} \mathrm{O}_{2}, p^{\text {Mod }}{ }_{a} \mathrm{CO}_{2}$ set equal to the experimentally $p_{a} \mathrm{O}_{2}$ and $p_{a} \mathrm{CO}_{2}$ respectively.

Computational experiments conducted with short-term adaptation of the mathematical model allow us to establish the specificity of the regulatory body's reactions to specific types of disturbances. Table 1 shows the data of oxygen and carbon dioxide stress calculations, the values of the flow rates of blood flow in the tissues during exercise and hypoxic hypoxia.

Analysis of the results of computational experiments with short-term adaptation model shows that under various conditions of vital activity required some kind of reaction of the circulatory system. Thus, in the simulation exercise volumetric blood flow velocity rises more than five times, increasing the value of volumetric blood flow in vital organs, although as a percentage of relations are not changed, except for the working skeletal muscles. Almost all organs and tissue oxygen tension regions stabilized at a lower level, and the carbon dioxide pressure - at a higher, indicating the development of the body hypoxia and hypercapnia.

Otherwise, short-term adaptation mechanisms to respond to the conditions when a person inhales hypoxic mixture. The volumetric flow rate under these conditions increases by about $5-10 \mathrm{ml} / \mathrm{s}$, although a huge increase in reserve. 
Table 1. Regulatory body reaction and oxygen tension, and carbon dioxide at various perturbation types (short-term adaptation)

\begin{tabular}{|c|c|c|c|c|c|c|c|}
\hline \multirow{2}{*}{$\begin{array}{c}\text { Type of } \\
\text { perturbation }\end{array}$} & \multirow{2}{*}{ Parameters } & \multicolumn{6}{|c|}{ Tissues ( $p \mathrm{O}_{2}$ and $p C \mathrm{O}_{2}$ in $\mathbf{m m ~} \mathbf{H g}, Q$ in $\mathbf{~ m l} / \mathbf{s}$ ) } \\
\hline & & Brain & heart & liver & kidneys & $\begin{array}{l}\text { skeletal } \\
\text { muscles }\end{array}$ & $\begin{array}{l}\text { other } \\
\text { tissues }\end{array}$ \\
\hline \multirow{3}{*}{$\begin{array}{l}\text { Exercise stress } \\
600 \mathrm{kgm} / \mathrm{min}\end{array}$} & $\mathrm{O}_{2}$ & 26,2 & 15,7 & 43,8 & 60,5 & 13,0 & 37,2 \\
\hline & $\mathrm{CO}_{2}$ & 51,1 & 57,2 & 50,2 & 45,0 & 54,0 & 47,8 \\
\hline & $Q_{t_{i}}$ & 23,5 & 29,5 & 42,6 & 16,0 & 298,8 & 11,4 \\
\hline \multirow{3}{*}{$\begin{array}{l}\text { hypoxic } \\
\text { hypoxia } \\
p_{a} O_{2}=70 . \\
p_{a} C O_{2}=30\end{array}$} & $\mathrm{O}_{2}$ & 32,2 & 20,8 & 38,1 & 44,0 & 26,0 & 36,1 \\
\hline & $\mathrm{CO}_{2}$ & 30,0 & 33,5 & 30,4 & 28,2 & 40,5 & 44,1 \\
\hline & $Q_{t_{i}}$ & 14,5 & 5,6 & 24,5 & 21,5 & 21,0 & 10,5 \\
\hline
\end{tabular}

The explanation of this fact (which coincides with the actual measurements) so that a substantial increase in the volumetric flow rate of the system, of course, would stabilize. $p_{t_{i}} O_{2}, i=\overline{1, m}$ at a higher level, but it would lead to a drop in $p_{t_{i}} C O_{2}, i=\overline{1, m}$ in tissues, to wash out the carbon dioxide in the body. The structure of the functional (11) takes into account both the hypoxic and hypercapnic stimuli regulating and determination $Q, Q_{t_{i}} i=\overline{1, m}$ conducted on the basis of a compromise. Hypoxia develops in the body, but there is no significant leaching of carbon dioxide.

\section{MATHEMATICAL MODEL OF THE MEDIUM-TERM ADAPTATION}

The mathematical model of the process of medium-term period of adaptation occurs when the disturbing factors act on the functional respiratory system either continuously or intermittently for a sufficiently long period of time (weeks, months). At this stage, except for short-term work arrangements to adapt, develop additional adaptive mechanisms that allow in response to outrage the best organization of metabolic functions in the tissues. It is known that the oxygen utilization in tissue reservoirs released the energy needed to do the work of muscles, supporting - motor system, maintain the basic functions of the organs. Part of the energy is released as heat and other species. Therefore, the rate of oxygen consumption in the tissues can be represented as:

$$
q_{t_{i}} O_{2}=q_{t_{i}}^{\phi} O_{2}+q_{t_{i}}^{m} O_{2}
$$

where $q_{t_{i}}^{\phi} \mathrm{O}_{2}$ - rate of consumption of oxygen necessary to perform a predetermined level functions of organs and tissues; $q_{t_{i}}^{m} \mathrm{O}_{2}$ - ate of oxygen consumption, providing the allocation of heat and other forms of energy. 
We can assume that for the work of a certain intensity $q_{t_{i}}^{\phi} \mathrm{O}_{2}=$ const, $i=\overline{1, m}$, while the second component may be reduced due to better organization of functions in the tissue region. We assume that

$$
\begin{gathered}
q_{t_{\text {adapt }}}^{m} O_{2}(\tau)=\left(q_{t_{\text {nadapt }_{i}}^{m}}^{m} O_{2}-q_{t_{\text {crit }_{i}}^{m}}^{m} O_{2}\right) * e^{-k \tau}+q_{t_{\text {crit }_{i}}^{m}}^{m} O_{2}, i=\overline{1, m} \\
q_{t_{\text {crit }}}^{m} O_{2}<q_{t_{\text {nadapt }_{i}}^{m}}^{m} O_{2},
\end{gathered}
$$

where $q_{t_{\text {adapt }}}^{m} \mathrm{O}_{2}$ - constituent rate of oxygen consumption, which is used to extract thermal energy in the adapted organism; $q_{t_{\text {nadap }_{i}}^{m}}^{m}$ - non-adapted to the body; $q_{t_{\text {crit }}}^{m} \mathrm{O}_{2}$ - rate of consumption of oxygen required to isolate the minimum amount of power while maintaining the heat balance in the adaptation.

The mechanism of medium adaptation presented by the relations (12) - (13) similar to person learning a certain type of work. The longer person performs the same kind of work, the better he does it with less effort.

Another mechanism is the adaptation medium change mechanism sensitivity coefficient to hypoxia $\rho_{1}$ and to hypercapnia $\rho_{2}$.

It can be assumed, that

$$
\begin{gathered}
\rho_{1_{\text {adapt }}}=\left(\rho_{1_{\text {nadapt }}}-\rho_{1_{\text {crit }}}\right) e^{-k_{1} \tau}+\rho_{1_{\text {crit }}} \\
\rho_{2_{\text {adapt }}}=\left(\rho_{2_{\text {adapt }}}-\rho_{2_{\text {crit }}}\right) e^{-k_{2} \tau}+\rho_{2_{\text {crit }}},
\end{gathered}
$$

where $\rho_{1_{\text {кpum }}}$ and $\rho_{2_{\text {кpum }}}$ minimum sensitivity coefficients to hypoxia and hyperoxia providing hypercapnic hypoxia and stimulation with the short adaptation mechanisms; $k_{1}$ and $k_{2}$ - ndividual coefficients of the adaptation for a particular organism. Note that if $q_{t_{i}}^{m} \mathrm{O}_{2}, q_{\text {tadapt }_{i}}^{m} \mathrm{O}_{2}, q_{t_{\text {nadapt }}}^{m} \mathrm{O}_{2}$ - the value of the biophysical, the $\rho_{1}$ and $\rho_{2}$ have a purely mathematical sense, but in a real organism clearly manifested their expression ensured by a system of different physiological mechanisms.

The mechanisms of medium-term adaptation in certain conditions of vital activity (impact of hypoxic hypoxia, hyperbaria) include erythropoiesis inclusion process - production of red blood cells by the bone marrow and release them into the blood or sequestration of erythrocytes, reducing them in the unit of blood volume. Mathematical model adaptation medium-term is the adaptation medium-term model for hypoxia supplemented by (13) - (15). As noted above, the short-term adaptation to hypoxia model is an optimal control problem dynamic system whose solution objectively difficult — a large number of differential equations governing parameters. It is possible to solve the optimization problem for such a system only at short time intervals (minutes). The medium-term adaptation occurs at longer intervals (days, weeks). Therefore, the use of simulation model of the system becomes ineffective. For this purpose, 
Table 2. Regulatory body reactions and the oxygen pressure and carbon dioxide at various perturbation types (medium-term adaptation)

\begin{tabular}{|c|c|c|c|c|c|c|c|}
\hline \multirow{2}{*}{$\begin{array}{c}\text { Type of } \\
\text { perturbation }\end{array}$} & \multirow{2}{*}{ Parameters } & \multicolumn{6}{|c|}{ Tissues ( $p \mathrm{O}_{2}$ and $p \mathrm{CO}_{2}$ in $\mathbf{m m ~} \mathbf{H g} ., Q$ in $\mathbf{m l} / \mathbf{s}$ ) } \\
\hline & & Brain & heart & liver & kidneys & $\begin{array}{l}\text { skeletal } \\
\text { muscles }\end{array}$ & $\begin{array}{l}\text { other } \\
\text { tissues }\end{array}$ \\
\hline \multirow{3}{*}{$\begin{array}{l}\text { Exercise stress } \\
600 \mathrm{kgm} / \mathrm{min}\end{array}$} & $\mathrm{O}_{2}$ & 28,1 & 16,1 & 44,2 & 62,3 & 13,3 & 37,0 \\
\hline & $\mathrm{CO}_{2}$ & 50,0 & 55,7 & 50,0 & 44,1 & 52,8 & 46,5 \\
\hline & $Q_{t i}$ & 22,3 & 28,0 & 41,8 & 15,8 & 287,7 & 10,8 \\
\hline \multirow{3}{*}{$\begin{array}{l}\text { hypoxic } \\
\text { hypoxia } \\
p_{a} \mathrm{O}_{2}=70,5 . \\
p_{a} \mathrm{CO}_{2}=30\end{array}$} & $\mathrm{O}_{2}$ & 33,0 & 22,6 & 39,2 & 45,1 & 27,0 & 36,4 \\
\hline & $\mathrm{CO}_{2}$ & 30,0 & 32,8 & 28,9 & 28,1 & 38,8 & 42,8 \\
\hline & $Q_{t i}$ & 13,5 & 5,4 & 23,1 & 20,6 & 20,5 & 9,81 \\
\hline
\end{tabular}

and has developed a new system of algebraic relations to predict the behavior of the respiratory system function at a sufficiently large time intervals.

Analysis of the mathematical model adaptation medium-term shows that the inclusion into the model relationships (13) - (15) increases the resource executive bodies regulation, in many cases, return values $V, Q, Q_{t_{i}}$ to levels they accepted the change to the life conditions.

Results of computational experiments with the mathematical model adaptation medium shown in Table 2 .

Note that the results of the modeling process medium adaptation to physical exercise performed under conditions at which $q_{t_{i}}^{m} \mathrm{O}_{2}$ was $5 \%$ of the level in the non-adapted organism. Similarly, data obtained by simulation under conditions of hypoxic hypoxia ( $\rho_{\text {adapt }}=0,95 \rho_{\text {nadapt }}$ ). The simulation results suggest that hypercapnia and hypoxia occurs in both cases, the values of $\mathrm{pO}_{2}$ in tissues at a higher level than in the short-term adaptation, although levels $Q_{t_{i}}, i=\overline{1, m}$. Decreased compared with calculated by short adaptation.

Returning to the same conditions of life, i.e. readaptation process, it proceeds at a significantly larger time interval and, in essence, is a process of long-term adaptation to a situation in which the influence of hypoxia is reduced.

\section{MATHEMATICAL MODEL OF THE LONG-IERM ADAPTATION}

Undoubtedly, the structural trace in the body's long-term adaptation leaves to the existing and effects on the body conditions of life. Regular high-intensity exercise, long-term stay in the mountains leads to a change in the mass of organs and tissues, especially those of the executive regulation of bodies such as the respiratory muscles and the heart muscle. Therefore, it can be assumed that the presence of functional (9) 


$$
\lambda_{t_{i}}=\varphi\left(\frac{V_{c t_{i}}}{V_{t_{i}}+\Delta V_{t_{i}}}\right), i=\overline{1, m}
$$

Accordingly, the change of the equation describing the changes in oxygen tension, and carbon dioxide in the tissue regions:

$$
\begin{gathered}
\frac{d p_{t_{i}} O_{2}}{d \tau}=\frac{1}{\left(V_{t_{i}}+\Delta V_{t_{i}}\right) \cdot\left(\alpha_{1 t_{i}}+\gamma_{M b} M b \frac{\partial \eta_{t_{i}}}{\partial p_{t_{i}}}\right)}\left(G_{t_{i}} O_{2}-q_{t_{i}} O_{2}\right), \\
\frac{d p_{t_{i}} C O_{2}}{d \tau}=\frac{1}{\left(V_{t_{i}}+\Delta V_{t_{i}}\right) \alpha_{2 t_{i}}}\left(G_{t_{i}} C O_{2}+q_{t_{i}} C O_{2}\right) .
\end{gathered}
$$

The analysis of equations (17), (18) and functional (9) shows that the reaction mechanisms of regulation, as a result of short-term adaptation, during long-term adaptation will be directed to oxygen stress stabilization and carbon dioxide in the tissue reservoirs at a higher level than it was during adaptation medium. In this case, the resources of the executive management bodies are significant, which allows to increase the volume and intensity of physical activity.

\section{CONCLUSIONS}

The model, which describes the mass transfer and mass exchange of respiratory gases in various parts of the respiratory system and the compensating effects of blood flow self-regulating mechanisms that stabilize the functional state of the body at a given level of its functional activity, is a controlled dynamic system, the state of which is determined at each moment by the stresses of oxygen and carbon dioxide in each structural link of the respiratory system (alveoli, blood and tissues). Regulation (self-regulation) of the state at a constant or at a given time interval of the current disturbance (high functional activity of individual tissue groups) is carried out by the executive bodies of self-regulation - the respiratory muscles, which form the necessary level of ventilation to compensate for the occurring hypoxic conditions, the heart muscle, which provides the minute volume of blood and smooth muscles tissue vessels.

This approach has been used on practice to calculate the self-organizatory respiratory system of functional parameter of persons at internal and external disturbances and can be used in the practice of occupational medicine and sports (athletes skilled in cyclic sports and combat sports, mountaineers, the operators of continuous interaction between systems) to predict functional status of persons engaged in extreme kinds of activities, the process of fatigue and recovery. 


\section{REFERENCES}

1. The secondary tissue hypoxia. Ed. A.Z. Kolchinskaya. Kyiv: Nauk. Dumka. 1983. (in Russian).

2. Kolchinskaya A.Z., Missyura A.G., Mankovskaya I. Breathing and oxygen regimes dolphins. Kyiv, 1980. (in Russian).

3. Onopchuk, Yu.N., Gritsenko V.I., Vovk M.I., Kotova A.B., Belov V.M., Mincer O.P., Kiforenko S.I., Kozak L.M., Ermakova I.I. Homeostasis of the functional respiratory system as a result of intrasystemic and systemic-environmental information interaction. In Bioecomedicine. Single information space. Kyiv: Nauk. Dumka, 2001, pp. 59-81 (in Russian).

4. Onopchuk, Yu.N., Gritsenko V.I., Vovk M.I., Kotova A.B., Belov V.M., Mincer O.P., Kiforenko S.I., Kozak L.M., Ermakova I.I. Homeostasis of the functional circulatory system as a result of intrasystemic and systemic-environmental information interaction. In Bioecomedicine. Single information space. Kyiv: Nauk. Dumka, 2001, pp.82-104 (in Russian).

5. Polinkevich K.B., Onopchuk Yu. M. Conflict situations during the regulation of main function of organism respiratory system and mathematic models for their solution. Cybernetics. 1986, no 3, pp. 100-104. (in Russian).

6. Aralova N.I. Mathematical model of the mechanism short- and medium-functional adaptation of breath of persons work in extreme conditions high. Kibernetika $i$ vyčislitelna $\hat{a}$ tehnika. 2015, no 182, pp. 15-25. (in Russian).

7. Aralova N.I., Beloshitsky P.V. The change of the parameters of athlete's respiratory system during adaptation to the mountain meteorological factors. Research based on the mathematical models. Sports Medicine. 2016, no 1, pp. 111-116. (in Russian).

\section{ЛІТЕРАТУРА}

Received 20.05.2019

1. Вторичная тканевая гипоксия / под общ. ред. А. 3. Колчинской. К.: Наук. думка. 1983. $253 \mathrm{c}$.

2. Колчинская А.З., Мисюра А. Г., Маньковская И. Н. Дыхание и кислородные режимы дельфинов. Київ.: Наук. думка, 1980. 332 с.

3. Онопчук Ю.Н., Гриценко В.И., Вовк М.И., Котова А.Б., Белов В.М., Минцер О.П., Кифоренко С.И., Козак Л.М., Ермакова И.И. Гомеостаз функциональной системы дыхания как результат внутрисистемного и системно-средового информационного взаимодействия. Биоэкомедицина. Единое информационное пространство. Киев, 2001. C. 59-81.

4. Онопчук Ю.Н., Гриценко В.И., Вовк М.И., Котова А.Б., Белов В.М., Минцер О.П., Кифоренко С.И., Козак Л.М., Ермакова И.И. Гомеостаз функциональной системы кровообращения как результат внутрисистемного и системно-средового информационного взаимодействия Биоэкомедицина. Единое информационное пространство. Киев. 2001. C. 82-104.

5. Полинкевич К.Б., Онопчук Ю.Н. Конфликтные ситуации при регулировании основной функции системы дыхания организма и математические модели их разрешения Кибернетика. 1986. № 3.С. 100-104.

6. Аралова Н.И. Математическая модель механизмов краткосрочной и среднесрочной адаптации функциональной системы дыхания лиц, работающих в экстремальных условиях. Кибернетика и вычислительная техника 2015. Вып. 182. С. 15-25.

7. Аралова Н.І., Білошицький П.В.Зміна параметрів функціонування системи дихання в процесі адаптації спортсменів до гірських метеофакторів. Дослідження на математичній моделі. Спортивна медицина. 2016. № 1. С. 111-116.

Отримано: 20.05.2019 
H.I. Аралова, канд. техн. наук, старш. наук. співроб., старш. наук. співроб. відд. оптимізації керованих процесів email: aralova@ukr.net

A.A. Аралова, канд. фіз.-мат. наук, наук. співроб. відд. методів дискретної оптимізації, математичного моделювання та аналізу складних систем. email: aaaralova@gmail.com

Інститут кібернетики ім. В.М. Глушкова НАН України, пр. Акад Глушкова, 40, м. Київ, 03187, Україна

\section{МАТЕМАТИЧНІ МОДЕЛІ КОНФЛІКТНО-КЕРОВАНИХ ПРОЦЕСІВ У РАЗІФУНКЦІОНАЛЬНОЇ САМООРГАНІЗАЦІЇ СИСТЕМИ ДИХАННЯ}

Вступ. Сучасна життєдіяльність людини вимагає від неї високої спроможності до адаптації у разіускладненні умов зовнішнього та внутрішнього середовища, таких як потенційна небезпека, підвищена відповідальність, дуже високі фізичні навантаження та їхня сумісна дія. Це призводить до погіршення показників геодинаміки, розладів функціональної діяльності інших органів та тканин. Вирішальна роль в адаптації організму до фізичних та психоемоційних навантажень належить киснево-транспортній системі. Проте наразі можливості інструментальних методів дослідження єдосить обмеженими, до того ж вони даютьзмогулише охарактеризувати стан організму в поточний момент, а не прогнозувати його резервні можливості у разі зовнішніх та внутрішніх збурень, в процесі відновлення та реабілітації.

Цю прогалину можуть частково заповнити математичні моделі функціональної системи дихання, які даютьзмогув динаміці дихального циклу імітувати збурення зовнішнього та внутрішнього середовища і таким чином прогнозувати можливі керувальні впливи органів саморегуляції для адаптації до цих збурень.

Мета. Побудувати математичну модель функціональної системи дихання, яка імітує розв'язання конфліктної ситуації між керувальними та виконавчими органами саморегуляції у боротьбі за кисень, яка надає можливість прогнозувати параметри самоорганізації системи дихання за внутрішніх та зовнішніх збурень.

Результати. Надано математичну модель масопереносу та масообміну респіраторних газів в організмі людини як систему диференційних рівнянь, яка $\epsilon$ керованою динамічною системою, стани якої визначаються у кожен момент напруженнями кисню та вуглекислого газу в кожній структурній ланці системи дихання (альвеолах, крові, тканинах). Керування (саморегуляція) станом на постійному чи на заданому відрізку часу задії збурення (висока функціональна активність окремих груп тканин) здійснюється виконавчими органами саморегуляції - дихальними м'язами, які формують необхідний рівень вентиляції для компенсації гіпоксичних станів, що виникають, серцевим м'язом, який забезпечує хвилинний кровообіг та гладенькими м'язами судин, вазодилатація та вазоконстрикція яких сприяє розподілу системного кровообігу по органах та тканинах. Також $є$ пасивні механізми саморегуляції - концентрація гемоглобіну в крові, міоглобіну в скелетних та серцевому м'язах, їхня здатність до оксигенації, концентрація буферних основ в крові тощо. Передбачається, що прийняття рішення щодо вибору величини компенсувального впливу приймається центром прийняття рішень на основі інформації щодо рівня функціональної активності та ступеня кисневої недостатності, надлишку накопичення вуглецю у всіх тканинних регіонах, передається на виконавчі органи саморегуляції, підвищує їхню функціональну активність, що забезпечує виконання основної функції системи дихання.

Висновки. Запропонована математична модель ФСД дає досліднику можливість проаналізувати кисневі та вуглекислотні режими організму в динаміці за різних рівнів функціонального навантаження і за різних умов середовища; сформувати такі режими системи зовнішнього дихання, які сприяють збільшенню запасів кисню в організмі і тим самим підвищують ресурс серцевого м'яза у регуляції гіпоксичних станів, які виникають за сумісної дії гіпоксичної гіпоксії та гіпоксії навантаження; спрогнозувати стан організму у разі різних фізичних зусиль та оцінити ефективність процесу підгото- 
вки; спланувати та розподілити важкі навантаження з урахуванням функціональних можливостей конкретногоіндивідуму та в залежності від наявнихумов. У роботі подано також результати обчислювальних експериментів у разі імітації внутрішніх (фізичне навантаження) та зовнішніх (гіпоксична гіпоксія) збурень на організм людини.

Ключові слова. Конфліктно-керовані прочеси, функціональна система дихання, самоорганізація системи дихання, адаптація до навантаження.

Н.И. Аралова, канд. техн. наук, старш. науч. сотр., старш. науч. сотр. отд. оптимизации управляемых процессов email: aralova@ukr.net

A. А. Аралова, канд. физ.-мат. наук

науч. сотр. отд. методов дискретной оптимизации, математического моделирования и анализа сложных систем email: aaaralova@gmail.com

Институт кибернетики имени В.М. Глушкова НАН Украины, пр. Акад. Глушкова 40, г. Киев, 03187, Украина.

\section{МАТЕМАТИЧЕСКИЕ МОДЕЛИ КОФЛИКТНО-УПРАВЛЯЕМЫХ ПРОЦЕССОВ ПРИ ФУНКЦИОНАЛЬНОЙ САМООРГАНИЗАЦИИ СИСТЕМЫ ДЫХАНИЯ}

Введение. Современная жизнедеятельность человека предъявляет все более жесткие требования к его способностям адаптироваться к усложняющимся условиям, таким как неблагоприятные условия окружающей среды, потенциальная опасность, повышенная ответственность, запредельные физические нагрузки и их сочетанное воздействие. Это приводит к понижению толерантности к физическим нагрузкам, неблагоприятным изменениям показателей гемодинамики, расстройствам функциональной деятельности других органов и тканей. Решающая роль в адаптации организма к физическим и психоэмоциональным нагрузкам принадлежит кислородо-транспортной системе. Однако в настоящее время возможности только инструментальных методов достаточно ограничены, к тому же они могут лишь характеризовать состояние организма только в текущий момент, а не прогнозировать его резервные возможности при возмущениях внутренней и внешней среды, в процессе восстановления и реабилитации.

Частично этот пробел могут заполнить математические модели функциональной системы дыхания, позволяющие в динамике дыхательного цикла имитировать возмущения внутренней и внешней среды организма и таким образом прогнозировать возможные управляющие воздействия органов саморегуляции организма при адаптации к этим возмущениям.

Цель. Построить математическую модель функциональной системы дыхания, имитирующую разрешение конфликтной ситуации между исполнительными и управляющими органами саморегуляции в борьбе за кислород, которая позволяет прогнозировать параметры самоорганизации системы дыхания при внутренних и внешних возмущениях.

Результаты. Представлена математическая модель массопереноса и массообмена респираторных газов в организме человека в виде системы нелинейных дифференциальных уравнений, являющую собой управляемую динамическую систему, состояние которой определяется в каждый момент времени напряжениями кислорода и углекислоты в каждом структурном звене системы дыхания (альвеолах, крови и тканях). Управление (саморегуляция) состоянием при постоянном или на заданном временном отрезке действующем возмущении (высокая функциональная активность отдельных групп тканей) осуществляется исполнительными органами саморегуляции - дыхательными мышцами, формирующими необходимый уровень вентиляции для компенсации возникающих гипоксических состояний, сердечной мышцей, обеспечивающей МОК, и гладкими мышцами тканевых сосудов, вазодилатация и вазокострикция которых способствует распределению системного кровотока по органам и тканям. Также присутствуют пассивные механизмы саморегуляции: концентрация гемоглобина в крови, миоглобина в скелетных и сердечной мышцах, их возможности к оксигенации, концентрация буферных основа- 
ний в крови и др. Предполагается, что решение о выборе величин компенсирующих воздействий принимается центром принятия решения на основании информации об уровне функциональной активности и степени кислородной недостаточности, избыточности накопления углекислоты во всех тканевых регионах организма, передается на исполнительные органы саморегуляции, повышает их функциональную активность, чем обеспечивается выполнение основной функции дыхания.

Выводы. Представленная математическая модель ФСД дает исследователю возможность проанализировать кислородные и углекислотные режимы организма в динамике при различных уровнях функциональной нагрузки и при различных условиях окружающей среды; сформировать такие режимы системы внешнего дыхания, которые способствуют увеличению запасов кислорода в организме и тем самым повышают ресурс сердечной мышцы при регуляции гипоксических состояний, которые возникают при сочетанном воздействии гипобарической гипоксии и гиперметаболической гипоксии; спрогнозировать состояние организма при различных физических усилиях и оценить эффективность процесса подготовки; спланировать и распределить тяжелые нагрузки с учетом функциональных возможностей данного индивидуума и в зависимости от складывающихся ситуаций. В работе представлены результаты численных экспериментов с моделью при имитации внутренних (физическая нагрузка) и внешних (гипоксическая гипоксия) возмущений на организм человека.

Ключевые слова: Конфликтно-упраляемые процессы, функииональная система дыхания,самоорганизаџия системы дыхания, адаптаџия к нагрузкам. 